Gut, 1989, 30, 347-354

\title{
Immunoglobulin secretion by isolated intestinal lymphocytes: spontaneous production and T-cell regulation in normal small intestine and in patients with coeliac disease
}

\author{
J E CRABTREE, R V HEATLEY, AND M L LOSOWSKY \\ From the Department of Medicine, St James's University Hospital, Leeds
}

SUMmaRY The in vitro secretion of immunoglobulins by small intestinal lymphocytes isolated from 47 patients with normal histology and 23 patients with treated and untreated coeliac disease was examined using an enzyme linked immunosorbent assay. In control patients, duodenal lymphocytes spontaneously secreted higher levels of IgM than jejunal lymphocytes $(\mathbf{p}<0 \cdot 05)$. Significantly higher levels of both IgA $(p<0.05)$ and IgM $(p<0.001)$ were secreted by jejunal lymphocytes of 10 patients with untreated coeliac disease than cells isolated from normal jejunal tissue. IgM and IgA secretion by duodenal lymphocytes isolated from control patients was increased in a dose dependent manner by coculture with autologous peripheral blood $T$ lymphocytes. This effect was not observed with jejunal lymphocytes of control or treated coeliac patients. Peripheral T-cells of untreated coeliac patients, however, showed significant helper effects $(p<0.05)$ for IgM and IgA secretion by autologous jejunal lymphocytes. The results suggest that jejunal lymphocytes of patients with untreated coeliac disease show major differences in their capacity to synthesise and secrete immunoglobulins in vitro and the enhanced secretion might result from changes in $T$-cell immunoregulatory function.

The mechanisms in: olved in the pathogenesis of coeliac disease are poorly understood. Although systemic cellular immune responses have been examined in detail,' investigations of mucosal immune responses have been limited. Immunohistological analysis of mucosal $\mathrm{T}$ lymphocytes has shown increased expression of stimulation markers and activation antigens ${ }^{23}$ and there have been varying reports of changes in plasma cell densities and isotype frequency. ${ }^{\text {th }}$ Alterations in mucosal architecture and surface to volume ratios associated with villous atrophy probably account for different results. ${ }^{7}$

Enhanced local secretion of immunoglobulins in coeliac patients has been demonstrated using in vitro organ culture systems ${ }^{\mathrm{s} x y}$ and the deposition of immune complexes may be important in mediating mucosal damage." Contamination of mucosally synthesised immunoglobulins by serum derived immunoglobulins, however, can not be excluded in these studies. The isolation of lymphoid cells from

Address for correspondence: Dr J Crabtree. Department of Medicine, St James's University Hospital, Leeds LS9 7TF.

Accepted for publication 25 August 1988. intestinal tissues by enzymatic digestion for short term in vitro culture ${ }^{1112}$ allows examination of mucosal responses at the cellular level. There have, however, been only limited studies of the functional capacity of isolated human small intestinal lymphocytes $^{13 / 4}$ and none pertaining to coeliac disease. In this study we have utilised cell isolation techniques, first to examine intestinal immunoglobulin secretion using isolated cell populations, and second to investigate the regulatory role of T lymphocytes on humoral intestinal responses. Abnormalities in humoral responses in coeliac disease may be secondary to abnormalities in $\mathrm{T}$ cell immunoregulation.

\section{Methods}

PATIENTS AND TISSUES

\section{Control patients}

Forty seven control patients were studied. Multiple biopsies were obtained from the second part of the duodenum of 25 patients (mean age $52 \cdot 1$, range 24 78) at endoscopy. Jejunal tissue was obtained from 22 
patients (mean age 37.9 years, range $16-64$ ) undergoing examination for possible coeliac disease using a Crosby capsule or a Quinton hydraulic multiple biopsy instrument. The mucosa of control patients was normal at histological examination and no other abnormalities were demonstrated in these patients.

This project was approved by the Committee for Clinical Research (Ethics) of the Leeds Eastern Health Authority (1985).

\section{Coeliac patients}

Jejunal biopsies were obtained from 23 patients with coeliac disease. Ten were untreated (two men, eight women; mean age $38 \cdot 1$ years, range $22-53$ ) on gluten containing diets at the time of biopsy. Five of the untreated patients had subtotal villous atrophy and five had severe partial villous atrophy on histological examination. Nine of the untreated patients have thus far shown histological improvement on gluten free diets. Jejunal biopsies were also obtained from one $\operatorname{IgA}$ deficient untreated coeliac patient (age 22) with subtotal villous atrophy. Jejunal biopsies were obtained from 12 treated coeliac patients (nine women, three men; mean age 32.9 years, range $17-$ 43 ), who had been on gluten free diets for a minimum of six months (maximum 12 years). Biopsies from nine patients were histologically normal, while three showed mild partial villous atrophy.

ISOLATION OF INTESTINAI IYYMPHOID CEILS Biopsies were collected into culture medium consisting of RPMI 1640) additionally buffered with $20 \mathrm{mM}$ HEPES (Flow Laboratories Ltd, Rickmansworth, Herts) and supplemented with $40 \mu \mathrm{g} / \mathrm{ml} \mathrm{Gentamycin}$ and $10 \%$ heat inactivated fetal calf serum (FCS, SeraLab Ltd, Crawley) (complete medium) and processed within one hour. Cells were isolated by a modification of the methods of Bull and Bookman," with the exception that no separate isolation of intraepithelial lymphocytes was undertaken. Briefly, mucus was removed from the biopsies by incubation for 15 minutes at $22^{\circ} \mathrm{C}$ in phosphate buffered saline (PBS) containing $1 \mathrm{mM}$ dithiothreitol (Sigma Chemicals, Poole). After washing four times in PBS, the tissue was finely minced and incubated for three hours with agitation in complete medium with 125 $\mathrm{U} / \mathrm{ml}$ collagenase (Type $1 \mathrm{~A}$, Sigma) at $37^{\circ} \mathrm{C}$. The crude cell suspension was layered over FCS to allow sedimentation of debris ${ }^{15}$ before centrifugation over Lymphoprep (Nyegaard, Norway) at $800 \mathrm{~g}$ (15 minutes). The interface cells were collected, washed twice in RPMI 1640 and resuspended in complete medium. Viability of the lymphocytes was assessed by Trypan blue exclusion. The above cell isolation procedures does not affect the capacity of peripheral lymphocytes to secrete immunoglobulins in vitro. ${ }^{\text {1n }}$
ISOLATION OF PERIPHERAI. BL.OOD

LYMPHOCYTES

Peripheral blood lymphocytes were isolated from heparinized venous blood, collected at the time of the investigative procedure, by centrifugation $(450 \mathrm{~g}, 20$ minutes) over Lymphoprep. Interface cells were washed twice with RPMI 1640 and T cell enriched fractions (PBT) were prepared by E-rosetting with 2-amino ethylisothiouronium bromide treated sheep red blood cells. ${ }^{17}$

IN VITRO IMMUNOGLOBUIIN SECRETION

Intestinal lymphocytes were cultured at $2 \times 10^{5}$ cells/ $\mathrm{ml}$ in 96 well round bottomed microtitre plates (Flow Laboratories) in a final volume of $200 \mu \mathrm{l}$. Cultures, set up in duplicate or where possible triplicate, were maintained in a $5 \% \quad \mathrm{CO}_{2}$ humidified incubator at $37^{\circ} \mathrm{C}$. After six days the culture supernatants were removed, centrifuged at $10000 \mathrm{~g}$ and stored at $-70^{\circ} \mathrm{C}$. Initial experiments showed that optimum immunoglobulin secretion occurred without the addition of pokeweed mitogen (Sigma, Poole) and mean intra-assay variability of cultures was $9.7 \%$. The regulation of immunoglobulin secretion was examined by coculturing intestinal mucosal lymphocytes from some patients with autologous PBT at ratios of $1: 1,1: 5$, and 1:10. Control cultures of PBT alone, with and without pokeweed mitogen, were performed for each experiment. For measurement of preformed intracellular immunoglobulins in mucosal lymphocytes, cells were frozen at $2 \times 10^{5} \mathrm{cells} / \mathrm{ml}$ for later sonication and assay.

MEASUREMENT OF IMMUNOGLOBULINS

The culture supernatants were assayed for total $\mathrm{IgG}$, $\operatorname{IgM}$, and $\operatorname{IgA}$ by enzyme linked immunoabsorbent assay (ELISA) as previously described. ${ }^{\text {Ix }}$ The amounts of secreted immunoglobulin were estimated from standard curves of human reference serum (Nyegaard) and the results expressed in $\mu \mathrm{g} / 10^{\mathrm{h}}$ cells. The detection limits for $\operatorname{IgG}$, IgM, and $\operatorname{IgA}$ were 65 , 43 , and $21 \mathrm{ng} / \mathrm{ml}$ respectively.

IMMUNOFLUORESCENCE ANALYSIS OF CFLI POPULATIONS

Air dried cytocentrifuged preparations (Shandon) of isolated mucosal lymphocytes and PBT were stored at $-70^{\circ} \mathrm{C}$ until processed. The percentage $\mathrm{Ig}+$ cells in the PBT preparations was assessed by direct immunofluorescence using fluorescein isothiocyanate (FITC) or tetraethyl rhodamine isothiocyanate (TRITC) conjugated antisera to human $\operatorname{lgG}$, IgA, IgD, and IgM (Dako Ltd, High Wycombe, Bucks). The ratios of CD4:CD8 in cell isolates were determined by double label immunofluorescence as previously described' using the monoclonal anti- 
bodies UCHT1 (CD3, IgG, Oxoid, Basingstoke) and RFT8 (CD8, IgM, Royal Free Hospital). Second layer goat antimouse Ig class specific antibodies were FITC conjugated anti-IgG and TRITC conjugated anti-IgM (Southern Biotechnology Associates Inc, USA). A minimum of 150 cells per isolate were examined on a Zeiss Standard microscope using epifluorescent illumination and selective filters for FITC and TRITC. The percentage CD4+ (helper/ inducer) cells was assessed by estimating the number of $\mathrm{CD} 3+$ cells which were CD8-.2

STATISTICAL ANALYSIS

Analysis of variance was carried out using the Kruskall-Wallis test. Statistical comparisons between mean values of unpaired data were carried out using the Mann-Whitney $U$ test for non-parametric data. Analysis of paired data was carried out using the Wilcoxon's signed-rank test.

\section{Results}

CELL YIELD AND CHARACTERISATION

The yield of mucosal lymphoid cells from normal duodenal and jejunal biopsies was $1 \cdot 1(0 \cdot 63) \times 10^{4}$ cells/mg wet weight. Biopsies from patients with treated and untreated coeliac disease yiclded $1 \cdot 18$ $(0.65) \times 10^{4}$ and $1.38(0.91) \times 10^{4}$ cells $/ \mathrm{mg}$ respectively. Viability of the isolated intestinal lymphocytes, as judged by Trypan blue exclusion, was greater than $95 \%$.

The ratio of CD4:CD8 $\mathrm{T}$ lymphocytes in the mucosal isolates from control and coeliac patients is shown in Figure 1. The mean CD4:CD8 ratio of jejunal lymphocytes of untreated coeliac patients was significantly higher $(\mathrm{p}<0.05)$ than that of control and treated coeliac patients. Peripheral blood $\mathrm{T}$ cell populations contained $<1 \% \mathrm{smIg}+$ cells. There was no significant difference between the mean CD4: CD8 ratios of $\mathrm{PBT}$ from control and coeliac patients (treated and untreated), which were 1.99:1 (0.72) $(\mathrm{n}=18)$ and $1 \cdot 81: 1(0 \cdot 61)(\mathrm{n}=12)$ respectively.

IMMUNOGLOBULIN SECRETION BY INTESTINAL LYMPHOCYTES

\section{Control patients}

The concentration of preformed immunoglobulins in the duodenal lymphocytes of six control patients was very low (mean values in $\mu \mathrm{g}$ per $10^{\circ}$ cells were $\operatorname{Ig} \mathrm{A}<0 \cdot 3 ; \operatorname{IgM}<0 \cdot 2 ; \operatorname{IgG}=0)$. The amounts of $\operatorname{IgA}$ and IgM secreted spontaneously in vitro during six days culture is shown in Figures 2 and 3 . $\operatorname{IgA}$ was the predominant immunoglobulin secreted by both duodenal and jejunal mucosal cells. The median amount of IgA produced by jejunal lymphocytes was

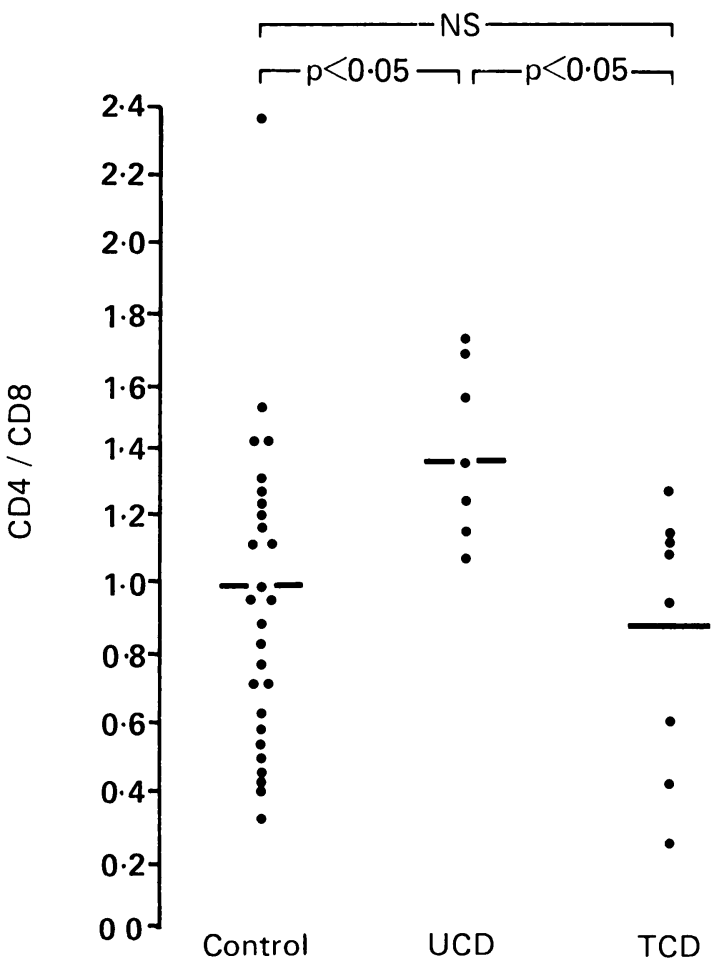

Fig. 1 CD4:CD8 ratio of intestinal lymphocytes isolated from control patients (duodenal and jejunal) and untreated (UCD) and treated coeliac (TCD) patients (jejunal).

approximately half that of the duodenal cells. The jejunal cells secreted significantly lower quantities of $\operatorname{IgM}(\mathrm{p}<0 \cdot(05)$ than the duodenal cells. No quantifiable IgG was secreted by jejunal lymphocytes and only very low levels were detected in duodenal culture supernatants $\left(0 \cdot 23(0 \cdot 07)\right.$ per $10^{\prime}$ cells $)$. There was no correlation between the CD4:CD8 ratio of the mucosal lymphocytes and the in vitro secretion of $\operatorname{IgM}$ or $\operatorname{Ig} \mathrm{A}$.

\section{Coeliac patients}

Isolated jejunal lymphocytes of patients with untreated coeliac disease secreted significantly higher amounts of $\operatorname{IgA}(\mathrm{p}<0 \cdot 05)$ and $\operatorname{IgM}(\mathrm{p}<0 \cdot(0) 1)$ during six days culture in vitro than jejunal lymphocytes from control patients (Figs 2,3). The IgM secretion was also significantly higher $(p<0 \cdot 01)$ than that of duodenal lymphocytes from normal patients. In contrast with the controls, in six of the 10 untreated coeliac patients, IgM was the predominant immunoglobulin secreted. The IgA secretion did not differ significantly from the duodenal control values. The median values for $\operatorname{IgA}$ and $\operatorname{IgM}$ secretion in the untreated coeliac patients were 2.9 and 5.5 times those of the jejunal controls. The IgA deficient 


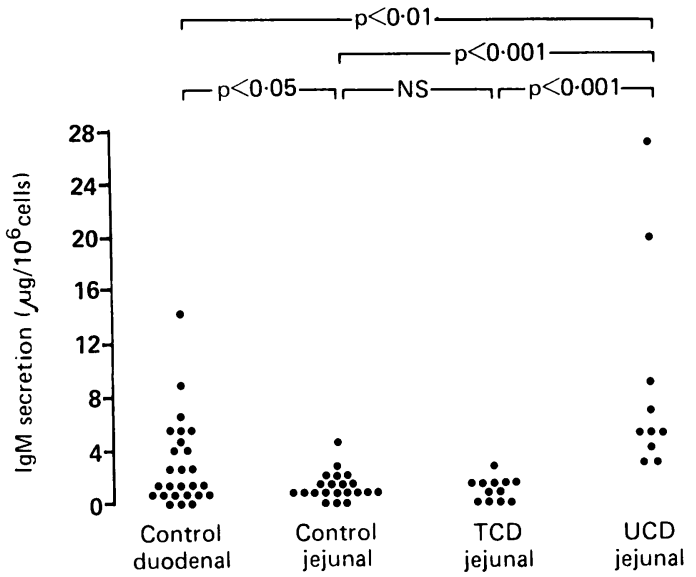

Fig. 2 Spontaneous IgM secretion in vitro during six days by intestinal lymphocytes from untreated $(U C D)$ and treated (TCD) coeliac and control patients. Kruskal-Wallis analysis of variance $(p<0 \cdot 001)$.

untreated coeliac patient secreted higher quantities of $\operatorname{IgM}\left(38 \mu \mathrm{g} / 10^{\circ}\right.$ cells $)$ than the patients with no $\operatorname{IgA}$ deficiency. Significant IgG secretion was detected in only four untreated coeliacs (values $2.75[\operatorname{IgA}$ deficient], $1 \cdot 25,1 \cdot 19$, and $0.48 \mu \mathrm{g} / 10^{\circ}$ cells).

In treated coeliac patients, the secretion of $\operatorname{IgA}$ and $\mathrm{IgM}$ by isolated lymphocytes was significantly less $(p<0.001)$ than that of untreated patients. The treated values did not differ significantly from those of jejunal cells from control patients.

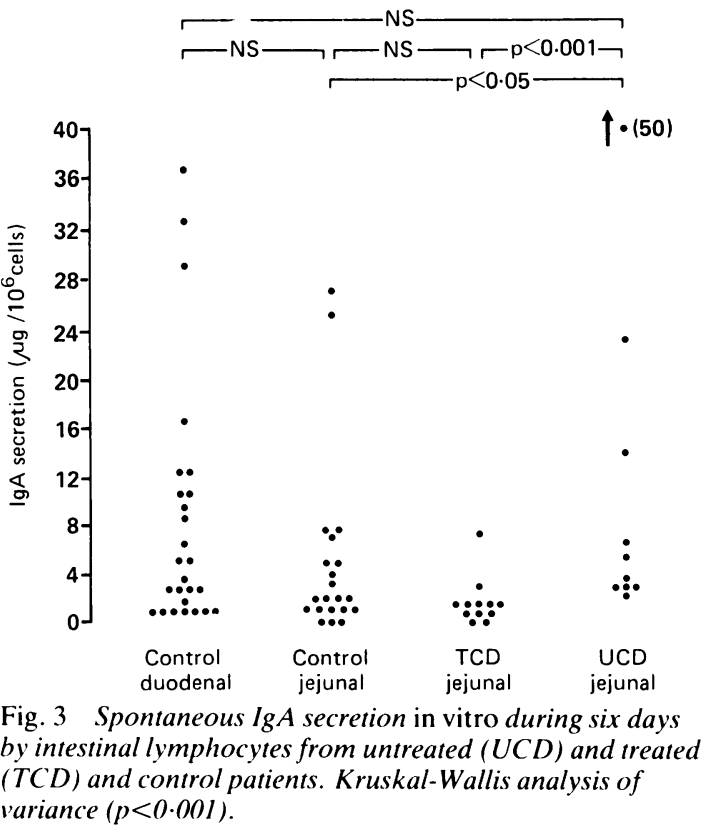

EFFECTS OF PERIPHERAL T CELLS ON

IMMUNOGLOBULIN SECRETION

\section{Control patients}

A dose dependent increase in both $\operatorname{IgA}$ and $\operatorname{Ig} M$ secretion by duodenal lymphocytes of control patients occurred on coculture with increasing concentrations of autologous peripheral $\mathrm{T}$ lymphocytes (Table). Significant increases were evident for both isotypes at ratios of 1:5 and 1:10 $(\operatorname{IgM} p<0.05 ; \operatorname{IgA}$ $\mathrm{p}<0.01$ by paired Wilcoxon's rank-test). Control cultures of PBT with and without pokeweed mitogen resulted in no measurable immunoglobulin secretion. Coculturing jejunal lymphocytes from control patients with autologous PBT had no significant effect on immunoglobulin secretion at any cell ratio (Table, Figs 4, 5), and suppression of $\operatorname{IgA}$ secretion occurred in two patients with high spontaneous $\operatorname{IgA}$ secretion (Fig. 5).

\section{Coeliac patients}

The $\operatorname{IgA}$ and $\operatorname{IgM}$ secretion of jejunal lymphocytes from untreated coeliac patients was significantly increased $(p<0.05)$ by coculture with autologous peripheral blood $\mathrm{T}$ lymphocytes (Figs 4,5 ). In treated coeliac patients no increase in $\operatorname{IgM}$ or $\operatorname{IgA}$ secretion on coculture with PBT was observed. Two coeliac patients, examined before and after gluten exclusion, showed a reduction in spontaneous immunoglobulin secretion and T-cell helper effects after treatment.

\section{Discussion}

The immunoregulatory control of humoral responses in the human intestine is not well understood. Local secretion will vary according to the number and

Table The effect of peripheral blood Tlymphocytes on the $\operatorname{Ig} M$ and $\operatorname{Ig} A$ secretion by duodenal and jejunal lymphocytes of control patients

\begin{tabular}{|c|c|c|}
\hline \multirow{2}{*}{$\begin{array}{l}\text { Ratio of mucosal } \\
\text { cells to PBT }\end{array}$} & \multicolumn{2}{|c|}{$\begin{array}{l}\text { Immunoglobulin secretion } \\
\text { mean }(S E)\left(\mu g / I \sigma^{\prime} \text { cells) }\right.\end{array}$} \\
\hline & $\lg M$ & $\lg A$ \\
\hline \multicolumn{3}{|c|}{ Duodenum $(n=13)$} \\
\hline $1: 0$ & $3.98(0.69)$ & $8.86(2 \cdot 4)$ \\
\hline $1: 1$ & $4.79(1.01)$ & $12 \cdot 63(3 \cdot 5)$ \\
\hline $1: 5$ & $* 5.70(1.12)$ & $* * 20.52(6.6)$ \\
\hline $1: 10$ & $* 6.98(1.7)$ & $* * 22 \cdot 70(6 \cdot 2)$ \\
\hline \multicolumn{3}{|c|}{ Jejunum $(n=9)$} \\
\hline $1: 0$ & $1.74(0.45)$ & $7 \cdot 59(3.54)$ \\
\hline $1: 5$ & $1 \cdot 24(0 \cdot 38)$ & $5.32(1.66)$ \\
\hline $1: 10$ & $2 \cdot 19(0.85)$ & $6 \cdot 44(2 \cdot(6)$ \\
\hline
\end{tabular}

Significance from 1:0, $\mathrm{p}<0 .\left(05,{ }^{* *} \mathrm{p}<0.01\right.$, by Wilcoxon's paired ranking test. 

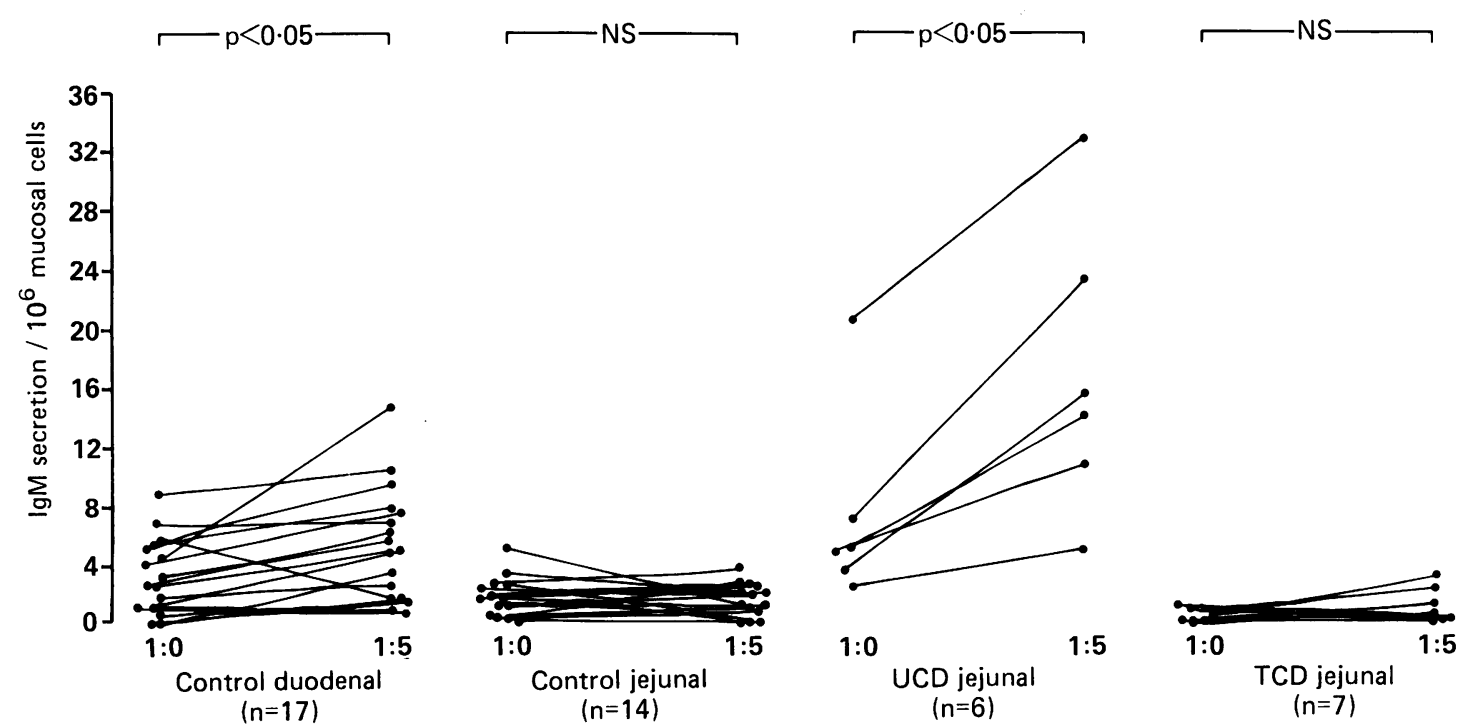

Fig. 4 Effect of autologous peripheral blood Tlymphocytes on the secretion of IgM by intestinal lymphocytes from untreated (UCD) and treated (TCD) coeliac and control patients. Ratio of mucosal cells to PBT 1:5.
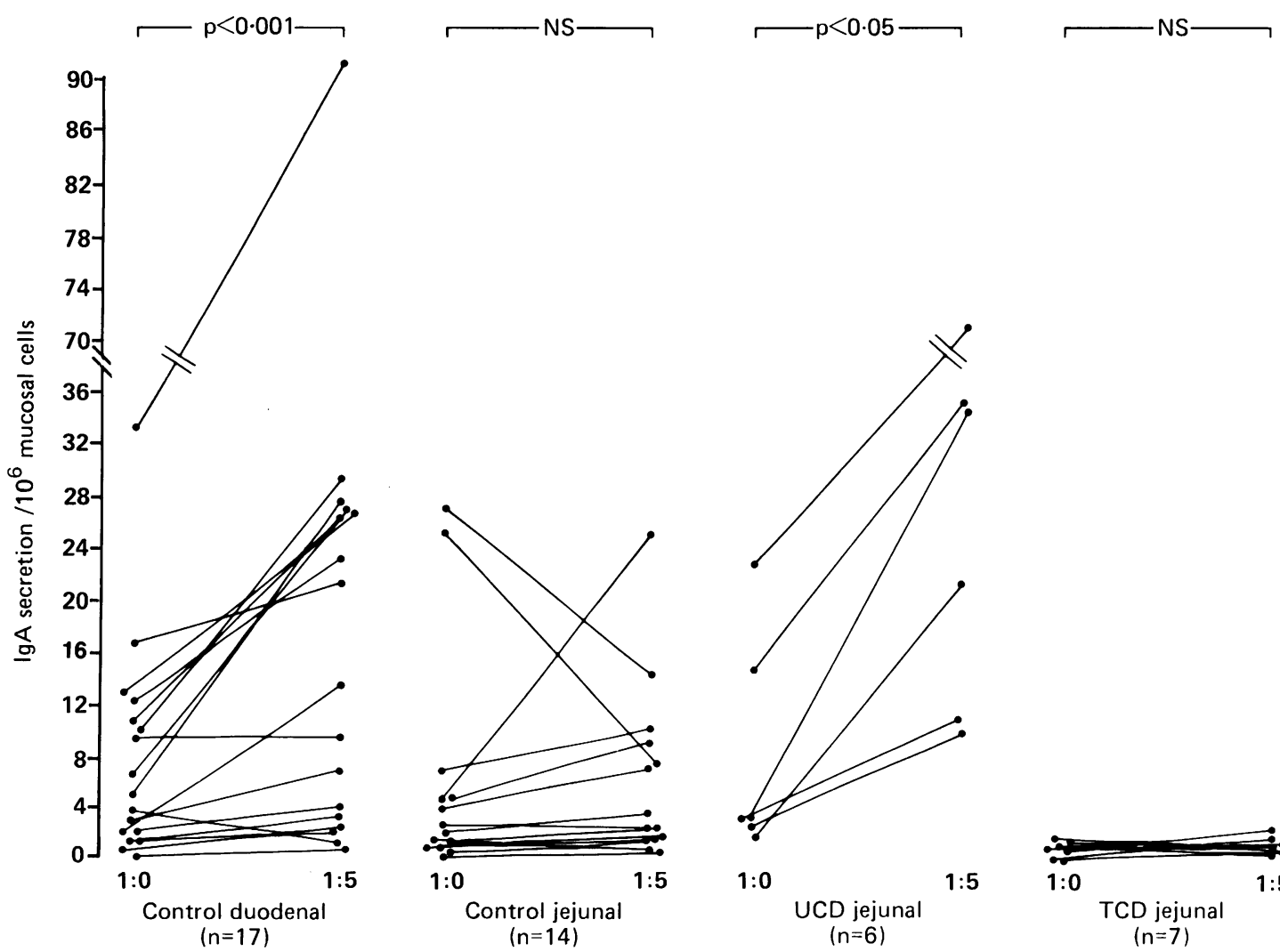

Fig. 5 Effect of autologous peripheral blood Tlymphocytes on the secretion of IgA by intestinal lymphocytes from untreated (UTC) and treated (TCD) and control patients. Ratio of mucosal cells to PBT I:5. 
functional activity of mucosal immunoglobulin containing cells. The role of T-cells in regulating humoral responses however is complex with secreted lymphokines such as B-cell growth factor and B-cell differentiation factors affecting both the proliferation and the terminal differentiation of $B$ lymphocytes into immunoglobulin secreting cells. ${ }^{14}$

In common with studies on isolated colonic and ileal human intestinal lymphocytes, ${ }^{, 122}$ the results of this study show that lymphocytes from normal duodenal and jejunal mucosa have the capacity to spontaneously secrete $\operatorname{IgA}$ and $\operatorname{IgM}$ in vitro. The amounts of immunoglobulins spontaneously secreted by duodenal and jejunal lymphocytes differed, with lower levels of IgM being evident in the jejunum. Reduced numbers of IgM plasma cells are evident distally in the intestinal tract, ${ }^{.3}$ which might account for the observed differences in patients with normal mucosa. Although the isotype distribution of immunoglobulin-containing cells in the lamina propria is not uniform from the muscularis mucosae to the sub-epithelial region, ${ }^{5}$ a different distribution of IgM cells at the two locations would appear unlikely. Such factors, however, should be considered when studying the functional properties of isolated mucosal cell populations.

Significant increases were apparent in the amount of IgM and $\operatorname{IgA}$ spontaneously secreted by mucosal lymphocytes of patients with untreated coeliac disease. The high levels of spontaneous mucosal IgM secretion contrast with the reduced serum IgM levels observed in untreated coeliac patients, ${ }^{24}$ suggesting a mucosal sequestration of sIgM-B cells rather than a specific defect in IgM production. Although the frequency of mucosal IgG plasma cells increases in coeliac disease, were observed in this study. This confirms and extends the observations of Wood $e t \mathrm{al}^{\circ}$ in which a rapid decrease in $\mathrm{IgG}$ secretion from jejunal tissue was observed after 24 hours culture in vitro. The increase in spontaneous secretion of $\operatorname{IgM}$ and $\mathrm{IgA}$ in untreated coeliac patients observed in this study parallels reported alterations in plasma cell isotype frequency, with the density of IgM plasma cells being increased relative to $\operatorname{IgA}$ cells.

Detailed phenotypic analysis of the isolated mucosal cells in coeliac patients was restricted by limited tissue availability. The mean CD4:CD8 ratio, however, of isolated jejunal lymphocytes from patients with untreated coeliac disease examined was significantly higher than that of control and treated coeliac patients. There is little alteration in the CD4:CD8 ratio of lymphocytes within the epithelium or lamina propria in coeliac disease. Intraepithelial lymphocytes are largely CD8+, however, ${ }^{25}$ and their absolute number per unit area of muscularis mucosae is reduced in untreated coeliac disease..$^{20}$ The higher CD4:CD8 ratio of the cell isolates in the untreated coeliac patients therefore is likely to reflect a reduced ratio of intraepithelial to lamina propria cells. A selective loss of CD8 cells during the cell isolation procedure ${ }^{27}$ restricted to untreated coeliac patients would appear unlikely. In untreated coeliac mucosa a higher proportion of CD8 cells co-express CD5, the function of these cells, however, is unknown.'

Despite the high spontaneous in vitro immunoglobulin secretion by normal duodenal lymphocytes, the mucosal cells were sensitive to helper influences of autologous PBT, $\operatorname{IgA}$ and $\operatorname{IgM}$ secretion being augmented in a dose dependent manner in coculture experiments. IgA secretion was particularly responsive to T-cell help, and it has been shown previously in humans that $\mathrm{T}$ helper cells for $\operatorname{IgA}$ are located both in the blood and secondary lymphoid tissue..$^{2 *}$ In contrast with the helper effects on $\operatorname{IgA}$ secretion, helper effects for IgM were relatively small but significant. Although the T-cell effects observed in this study were not isotype specific, the presence of separate $\mathrm{T}$-cell populations with isotype-specific influences on terminal differentiation cannot be excluded. The observed helper effects on duodenal immunoglobulin secretion might, however, result from a complex interaction between mucosal immu-

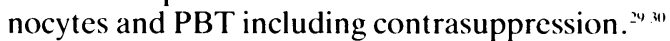

The variation in response of jejunal lymphocytes of control patients is enigmatic. Low numbers of IgM responder cells might preclude the demonstration of T-cell helper effects for this isotype, but differences in $\operatorname{IgA}$ responsiveness relative to the duodenal lymphocytes might reflect the normal in vivo activation level of mucosal $B$ or $T$ cell populations. Alternatively the non-responsiveness of jejunal lymphocytes of control patients might be a consequence of a higher level of suppressor cell activation in the isolated mucosal population.

The significant T-cell helper effects, particularly for IgM, observed in untreated coeliac patients contrast markedly with the results obtained with normal jejunal tissue. A defect in T-cell regulation of intestinal humoral responses might account for local plasma cell infiltration.? Alternatively, the changes might reflect altered cell populations secondary to tissue damage. Although no changes in the CD4: CD8 ratio of peripheral lymphocytes, as determined by monoclonal markers, is evident in coeliac disease,,$^{31}$ other studies have emphasised the heterogeneity of human regulatory $T$ cell populations. "'Enhanced mucosal immunoglobulin synthesis could result from failure of suppressor cell function or increased contrasuppressor activity. ${ }^{33}$

The observed perturbations in humoral mucosal responses in untreated cocliac patients may therefore 
reflect changes in regulatory $T$ cell populations. With increasing characterisation of human $T$ cell subsets, greater understanding of the immunoregulatory function of $T$ cells in humoral responses in coeliac patients should be possible.

This work was supported by the Medical Research Council. We would like to thank Dr J Findlay, and the staff of the Gastroenterology Departments of Bradford Royal Infirmary and St James's University Hospital for their cooperation and $\mathrm{Dr}$ L K Trejdosiewicz for valuable discussions.

\section{References}

1 Strober W. Gluten-sensitive enteropathy, an abnormal immunologic response of the gastrointestinal tract to a dietary protein. In: Shortner RG, Kirsner JB, eds. Gastrointestinal immunity for the clinician. Orlando: Grove \& Stratton Inc, 1985: 75-112.

2 Malizia G, Trejdosiewicz LK, Wood GM. Howdle PD. Janossy G, Losowsky MS. The microenvironment of cocliac disease: $T$ cell phenotypes and expression of the $\mathrm{T} 2$ ' $\mathrm{T}$ blast' antigen by small bowel lymphocytes. Clin Exp Immunol 1985; 60: 437-46.

3 Kelly J, O'Farrelly C, O'Mahoney C, Weir DG, Feighery C. Immunoperoxidase demonstration of the cellular composition of the normal and cocliac small bowel. Clin Exp Immunol 1987; 68: 177-88.

4 Lancaster-Smith M, Kumar P. Marks R. Clark ML. Dawson AM. Jejunal mucosal immunoglobulincontaining cells and jejunal fluid immunoglobulins in adult coeliac disease and dermatitis herpetiformis. Gut 1974; 15: 371-6.

5 Bakelien K, Brandtzacg P, Fausa O. Immunoglobulins in jejunal mucosa and serum from patients with adult coeliac disease. Scand J Gastroenterol 1977; 12: 149-59.

6 Wood GM, Howdle PD, Trejdosiewicz LK. Losowsky MS. Jejunal plasma cells and in vitro immunoglobulin production in adult cocliac discase. Clin Exp Immunol 1987; 69: 123-32.

7 Dhesi I, Marsh MN, Kelly C, Crowe P. Morphometric analysis of small intestinal mucosa. 2. Determination of lamina propria volumes; plasma cell and ncutrophil populations within control and cocliac diseasc mucosac. Virchows Arch /Pathol Anat] 1984; 403: 173-80.

8 Fluge G, Aksnes L. Quantification of immunoglobulins after organ culture of human duodenal mucosa. J Pediatr Gastroenterol Nutr 1983; 2: 62-70.

9 Wood GM, Shires S, Howdle PD, Losowsky MS. Immunoglobulin production by cocliac biopsics in organ culture. Gut 1986; 27: 1151-60.

10 Scott BB, Scott DG, Losowsky MS. Jejunal mucosal immunoglobulins and complement in untreated cocliac disease. J Pathol 1977; 121: 219-23.

11 Bull DM, Bookman MA. Isolation and functional characterisation of human intestinal mucosal lymphoid cells. J Clin Invest 1977; 59: 966-74.

12 Crofton RW, Cochranc C, McClelland DBL. Preparation of lymphoid cells from small specimens of human gastrointestinal mucosa. Gut 1978; 19: 898-906.
13 Goodacre R, Davidson R. Singal D, Bienenstock J. Morphologic and functional characteristics of human intestinal lymphoid cells isolated by a mechanical technique. Gastroenterology 1979; 76: 300-8.

14 Elson CO, Weiserbs DB, Ealding W, Machelski E. T-helper cell activity in intestinal lamina propria. Ann NY Acad Sci 1983; 409: 230-7.

15 Shortman K. Williams N. Adams P. The separation of different cell classes from lymphoid organs. 5. Simple procedures for the removal of cell debris, damaged cells and erythroid cells from lymphoid cell suspensions. J Immunol Methods 1972; 1: 273-87.

16 Smart CJ. Trejdosiewicz LK, Badr-cl-Din S, Heatley RV. T lymphocytes of the human colonic mucosa: functional and phenotypic analysis. Clin Exp Immunol 1988: 73: 63-9.

17 Jondall M. Holm G. Wigzell H. Surface markers on human $\mathrm{T}$ and $\mathrm{B}$ lymphocytes. 1. A large population of lymphocytes forming nonimmune rosettes with sheep red blood cells. $J$ Exp Med 1972; 136: 207-15.

18 Wood GM, Trejdosiewicz LK, Losowsky MS. ELISA for measurement of secretory $\operatorname{IgA}$ distinct from monomeric IgA. J Immunol Methods 1987b; 97: 269-74.

19 Jelinik DJ, Lipsky PJ. Regulation of human B lymphocyte activation, proliferation, and differentiation. Adv Immunol 1987; 40: 1-59.

20) MacDermott RP. Nash GS, Bertovich MJ, Seiden MV. Bragdon MJ, Beale MG. Alterations of IgM, IgG, and IgA synthesis and secretion by peripheral blood and intestinal mononuclear cells from patients with ulcerative and Crohn's discase. Gastroenterology 1981; 81: 844-52.

21 MacDermott RP. Nash GS. Bertovich MJ. et al. Altered patrens of secretion of monomeric $\operatorname{IgA}$ and $\operatorname{IgA}$ subclass 1 by intestinal mononuclear cells in inflammatory bowel disease. Gastroenterology 1986; 91: 379-85.

22 Danis VA. Heatley RV. Evidence for regulation of human colonic mucosal immunoglobulin secretion by intestinal lymphoid cells. J Clin Lab Immunol 1987; 22: $7-11$.

23 Brandtzacg P. The B cell system. In: Brostoff J, Challacombe SJ, eds. Food allergy and intolerance. Sussex: Baillière Tindall, 1987: 118-55.

24 Hobbs JR, Hepner CW. Deficiency of M-globulin in coeliac disease. Lancet 1968; i: 217-20.

25 Selby WS, Janossy G. Jewell DP. Immunohistological characterisation of intraepithelial lymphocytes of the human gastrointestinal tract. Gut 1981; 22: 169-76.

26 Marsh MN. Cocliac disease. In: Marsh MN, ed. Immunopathology of the small intestine. Chichester: John Wiley, 1987: 371-99.

27 Selby WS, Janossy G, Bofill M. Jewell DP. Intestinal lymphocyte subpopulations in inflammatory bowel disease: an analysis by immunohistological and cell isolation techniques. Gut 1984; 25: 32-40.

28 McCaughan GW. Adams E, Basten A. Human antigenspecific IgA responses in blood and secondary lymphoid tissuc: an analysis of help and suppression. J Immunol 1984; 132: 1190-6.

29 Gershon RK. Eardley DD. Durum S. et al. Contrasuppression: a novel immunoregulatory activity. $J$ Exp Med 1981: 153: 1533-46. 
30) Lehner T, Avery J, Jones T. Separation and characterization of a subset of human T8+ cells which function as antigen-presenting and contrasuppressor cells. Immunology 1985; 54: 713-22.

31 Selby WS, Janossy G, Bofill M, Jewell DP. Lymphocyte subpopulations in the human small intestine. The findings in normal mucosa and in the mucosa of patients with adult cocliac discase. Clin Exp Immunol 1983; 52: 219 28.
32 Thomas Y, Rogoziuski L. Chess L. Relationship between human T-cell functional heterogenicity and human T-cell surface molecules. Immunol Rev 1983; 74: 113-28.

33 Green DR, Gold J. St Martin S, Gershon R, Gershon RK. Microenvironmental immunoregulation: possible role of contrasuppressor cells in maintaining immune response in gut-associated lymphoid tissues. Proc Natl Acad Sci USA 1982; 79: 889-92. 